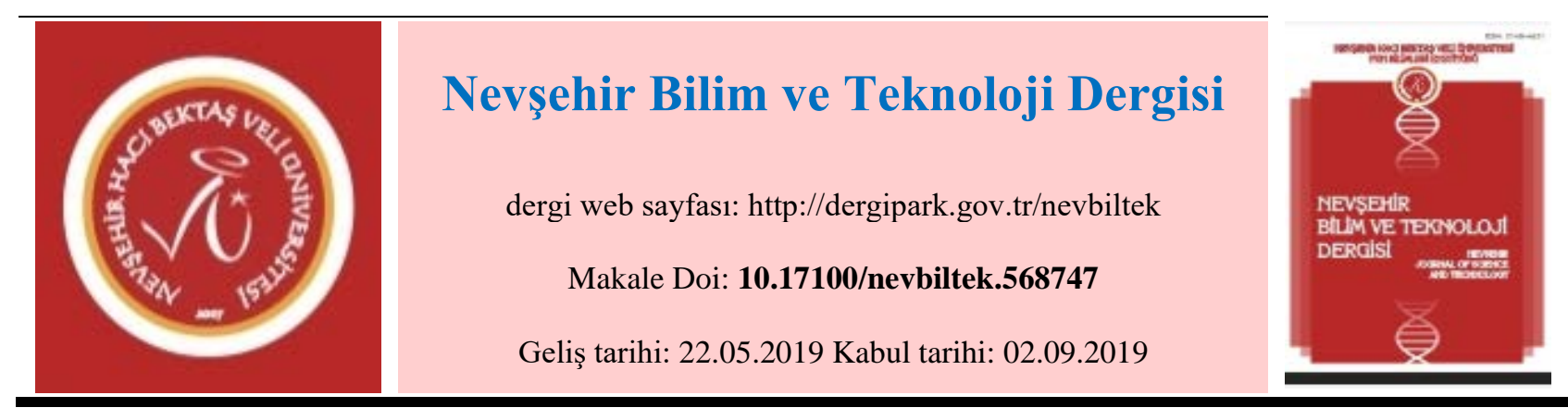

\title{
Yenilenen Park Alanlarında İklim Odaklı Tasarımlar: Erzurum Kentsel Dönüşüm Alanı Örneği 1
}

\author{
Hasan YILMAZ ${ }^{1}$, Sevgi YILMAZ ${ }^{2}$, Emral MUTLU ${ }^{3}$ \\ ${ }^{1}$ Atatürk Üniversitesi, Mimarlık ve Tasarım Fakültesi, Peyzaj Mimarlı̆̆ı Bölümü, Erzurum \\ ORCID ID: 0000000337684760 \\ ${ }^{2}$ Atatürk Üniversitesi, Mimarlı ve Tasarım Fakültesi, Peyzaj Mimarlığı Bölümü, Erzurum \\ ORCID ID: 0000000176685788 \\ ${ }^{3}$ Atatürk Üniversitesi, Mimarlık ve Tasarım Fakültesi, Peyzaj Mimarlığı Bölümü, Erzurum \\ ORCID ID: $000000034097067 \mathrm{X}$
}

Öz

Günümüzdeki uygulanan parklarda sert zemin oranlarının gitgide arttığı çalışmalar ortaya çıkmakta ve bitkisel materyal kullanımı azalmaktadır. Ayrıca yeni yapılan parkların çoğunda işlevsellikten önce estetik değere sahip bitkisel materyallerin kullanıldığı görülmektedir. Bu gözlemler sonucunda sert zeminlerin artmasının kentlerimizdeki iklimi nasıl etkilediği merak konusudur. Çalışma alanı Erzurum Kalesi’nin batısında yer alıp kentsel dönüşüm alanı kapsamında bulunmaktadır. Mevcutta otopark olarak kullanılan ve ezilmiş toprak örtüsüne sahip alana; 5 farklı senaryo ile beraber sert zemin oranlarının değiştiği tasarımlar yapılmıştır. Yapılan tasarımlar ENVI-met programıyla değerlendirmeye alınmıştır. Bu tasarımlar kapsamında sert zemin oranı arttıkça iklim odaklı dış mekan termal konforunun olumsuz yönde etkilendiği çalışma sonucunda tespit edilmiştir. Yapılan bu tespitler Predicted Mean Vote (PMV) standartlarına göre belirlenmiştir. Ayrıca çalışma sonucunda bitkilerin kullanım şekilleri ve yerlerinin de önem kazandığı sonucuna varılmıştır. Çalışma alanında park içerisindeki dış mekan termal konforunu etkili bir şekilde arttıran parametreler; yeşil alanların artması, ağaçların kullanılması ve çalıların ağaçlarla birlikte kullanılması olarak belirlenmiştir. Sonuç olarak; tasarım yapılan park alanı için yeşil alan kullanımı oranı azaldıkça, dış mekan termal konforunun "termal stressiz" aralığından "hafif sıcaklık stresli" ya da "sıcaklık stresli" aralığına geçiş yaptı̆̆ı tespit edilmiştir.

Anahtar Kelimeler: Kentsel dönüşüm alanı, İklim odaklı peyzaj, Dış mekan termal konforu, Erzurum

\section{Climate-Oriented Designs in Renewed Parking Areas: Erzurum Urban Transformation Area Case}

Abstract

In today's applied parks, hard floor rates are increasing and the use of plant material is decreasing. In addition, in most of the new parks, it is seen that plant materials with aesthetic value are used before functionality. As a result of these observations, it is curious to see how the increase of hard surfaces affected the climate in our cities.

The study area is located in the west of Erzurum Castle and is within the scope of urban transformation area. In the area with crushed land cover, which is used as a car parking area, designs with 5 different scenarios and hard floor rates were changed.

The designs were evaluated by ENVI-met program. As the hard floor ratio increases; climate-oriented outdoor thermal comfort was affected negatively in the study. These determinations were made according to Predicted Mean Vote (PMV) standards. In addition, it is observed that the use of plants and their places have gained importance. Factors that change positively the outdoor thermal comfort of the space in the park; the increase in green areas, the use of trees and the use of trees with shrubs.

As a result, as the ratio of green space usage for the designed parking area decreases; It has been determined that the thermal comfort of the outdoor thermal comfort shifts from the "Comfortable" range to the "Slight Heat Stress" or "Modereta Heat Stress" range.

Keywords: Urban transformation area, Climate-oriented landscape, Outdoor thermal comfort, Erzurum

${ }^{1}$ Bildirinin özeti "2nd International Congress on Engineering and Architecture " kongresinde özet olarak sunulmuştur.

Sorumlu yazar e-mail: hyilmaz@atauni.edu.tr 


\section{Giriş}

Hızlı kentleşme sadece insanların olanaklarını olumlu yönde arttırmak gibi pozitif etkilere sahip değildir. Bu olumlu etkilerin yanında kentsel alanlarda geçirimsiz yüzeylerin artması, yeşil alanların azalması, daha çok konut ve iş yeri inşa edilmesi ve daha çok kişisel araç kullanımına bağı olarak Kentsel Isı Adası (KIA) oluşumuna neden olmaktadır [1;2]. Ayrıca KIA sadece kentlerin 1sınması ya da iklim değişikliğini değil kentlerdeki kirleticilerin yoğunluğunu [3] da arttırmaktadır. Günümüzde dünya nüfusunun $\% 55$ 'i kentlerde yaşarken 2050 y1lında dünya nüfusunun \%68'inin kentlerde yaşaması beklenmektedir [4]. Bütün bu araştırmalara dayanarak günümüzdeki kötü kentleşme şartlarının gelecekte de oldukça hızlı bir şekilde artacağı ve artan emisyon değerleri ile beraber 2030-2052 yılları arasında $1{ }^{\circ} \mathrm{C}$ isınan dünyanın $1,5{ }^{\circ} \mathrm{C}$ isınma sınırına ulaşacağ $[5]$ tahmin edilmektedir. Bütün bu olumsuz durumları engellemek ya da mevcuttaki durumu korumak daha kötüye gitmesini engellemek adına birçok çalışma yapılmıştır. Bu çalışmalardan bazıları; kentsel ısı adası [6; 7; 8], kentsel tasarımın iklime adaptasyonu [9; 10;11; 12], dış mekanda yaya termal konforu $[6 ; 7 ; 9 ; 10 ; 11 ; 12 ; 13]$, kentlerin termal konfor haritalarının oluşturulması [15; 16; 17; 18; 19] ve kentsel yeşil alanların KIA'ları üzerindeki etkisi [1] konularında araştırılmıştır.

Kentsel yeșil alanların daha etkili kullanımı ve tasarlanması peyzaj mimarlığının dıs mekan termal konforunu sağlaması bakımından oldukça büyük önem taşımaktadır. Dış mekan termal konforu sağlayacak ana peyzaj parametreleri bitki örtüsü, su varlığı, sert zemin kullanımı ve gölgeleme elemanları olarak sıralanmaktadır [7; 20; 21; 22; 23].

Bu çalışma; Erzurum kentinde yer alan küçük kentsel yeşil alanların (0.39 ha/3915 m2) diş mekan termal konforuna olan etkisini araștırmaktadır. Ayrıca çalıșma alanı Erzurum Kalesi'nin batısında bulunan kentsel dönüşüm alanı kapsamındadır. Bu kapsamda mevcut alana ek olarak sert zemin oranlarının değiştiği 5 farklı tasarıma sahip kullanım şekli önerilmiştir.

\section{Materyal ve Metot}

Çalışma alanı; Erzurum kent merkezinde tarihi dokunun yoğun olarak yer aldığı ve kentsel dönüşüm alanı içerisinde bulunmaktadır. Mevcut durumda araçların otopark olarak kullandığı ve ezilmiş toprak katmanından oluşan, 3915 m2 (0.39 ha) büyüklüğe sahip bir alandır. Alanın kuzeyinde restore edilmiş tarihi Erzurum evleri, doğusunda Erzurum Kalesi ve önündeki park alanı, batısında işyerleri/konutlar son olarak güneyinde ise camii ve bir iş hanı bulunmaktadır. Alanda mevcut 2 adet Robinia pseudoacacia bulunmaktadır. Çalışma alanının 2005 yılından itibaren uğradığı değişime Şekil 1'de yer verilmiştir.

Ayrıca çalı̧̧ma alanının bulunduğu Erzurum iline ait hakim rüzgar yönü Güney-Batı ve ortalama rüzgar hızı $2.7 \mathrm{~m} / \mathrm{s}$ 'dir. Çalışma alanının değerlendirildiği Eylül ayı için 1929-2017 yılları arasındaki en yüksek sıcaklık değeri 33.3 ${ }^{\circ} \mathrm{C}$ iken en düşük sıcaklık değeri $-6.6^{\circ} \mathrm{C}$ olarak tespit edilmiş̧ir. Erzurum'un Eylül ayı ortalama sıcaklık değeri ise 14.7 ${ }^{\circ} \mathrm{C}$ 'dir [24]. 


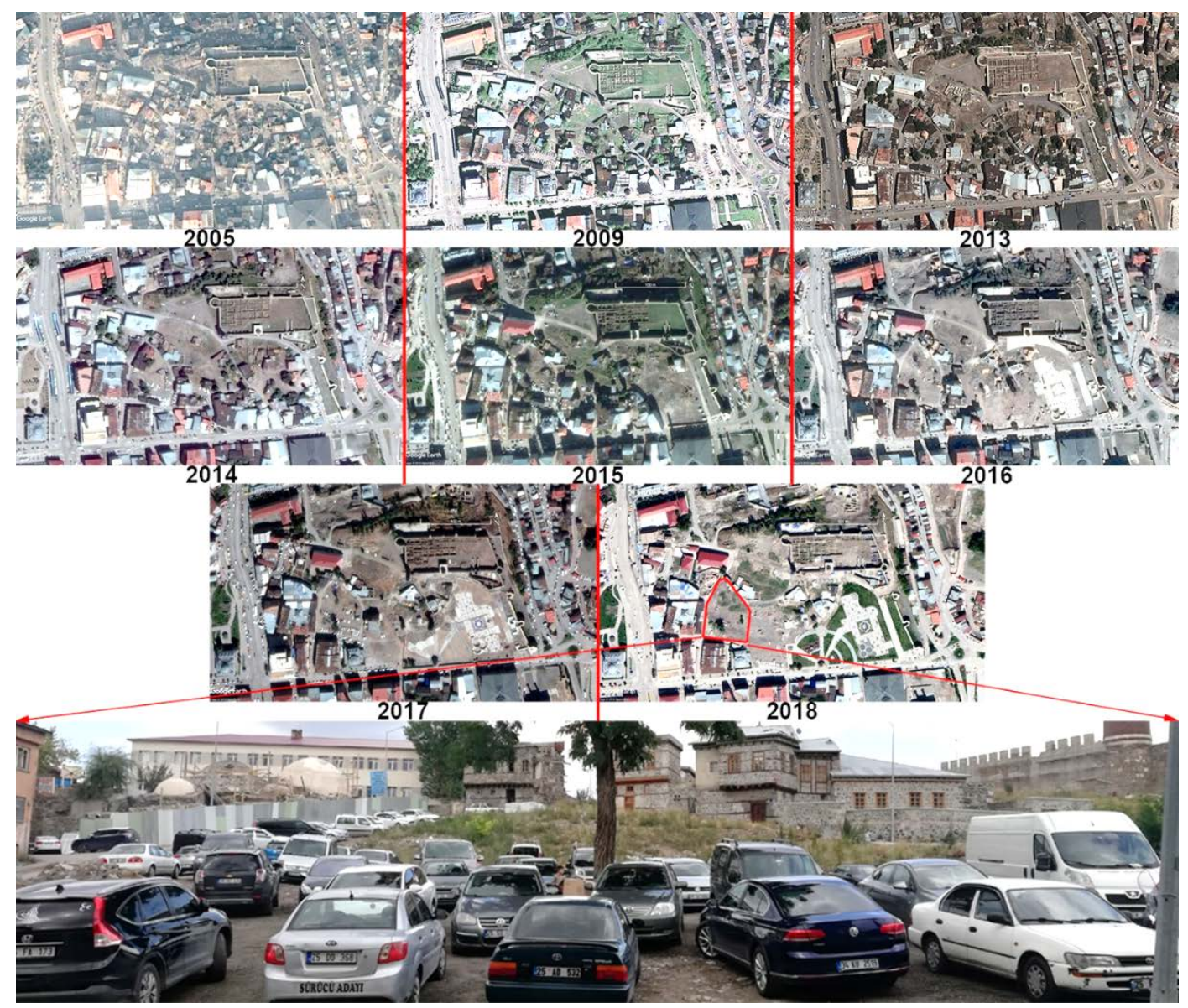

Şekil 1. Çalışma alanı ve çevresine ait 2005- 2018 yılları arasındaki dönüşüm

Erzurum kent merkezinde bulunan çalışma alanında yerden 1.5m yükseklikten; 11.09.2018/12.09.2018 tarihlerinde toplamda 28 saatlik iklim verileri (sıcaklık, nem, rüzgar yönü ve hızı) elde edilmiştir. Kentsel dönüşüm kapsamında olan çalışma alanı için \%80, \%70, \%60, \%50 ve \%40 oranında yeşil alanların olduğu tasarımlar yapıılmıştır. Yapılan tasarımlar Envi-Met programı ile sayısallaştırılarak alınan iklim verileri işlenerek mevcut duruma göre tasarımların iklime nasıl bir etki göstereceği tespit edilmiştir. Alanda bulunan 2 adet ağaç bütün tasarım senaryolarında korunmuştur. Çalışma alanı ile ilgili Envi-Met programında kullanılan verilere Tablo 1'de yer verilmiştir.

Tablo 1. Çalışma alanına Envi-Met programında kullanılan veriler

\begin{tabular}{|c|c|}
\hline Konum & Erzurum Kent Merkezi \\
\hline İklim Tipi & Dağ Ekosistemi \\
\hline \multicolumn{2}{|l|}{ Simülasyon Periyodu } \\
\hline Toplam Simülasyon Süresi & Her proje için 18 saat \\
\hline Çalışma Çözünürlüğü & $1 \mathrm{mx} 1 \mathrm{~m} \times 1 \mathrm{~m}$ \\
\hline Çalışma Alanı Büyüklüğüu & $90 \mathrm{~m} \times 70 \mathrm{~m} \times 30 \mathrm{~m}$ \\
\hline Model Rotasyonu & $0^{\circ}$ \\
\hline Tarih & 11.09.2018 \\
\hline \multicolumn{2}{|l|}{ Temel Meteorolojik Girdiler } \\
\hline Rüzgar Hızı (m/s) & 0.6 \\
\hline Rüzgar Yönü ( $\left.{ }^{\circ}\right)$ & $\left(270^{\circ}\right)$ \\
\hline 24 Saatlik Hava Sıcaklığı & + (Basit Zorlama) \\
\hline 24 Saatlik Bağıl Nem & + (Basit Zorlama) \\
\hline En Düşük Hava Sıcaklığ $\left({ }^{\circ} \mathrm{C}\right) / \mathrm{h}$ & $-9.1 / 04: 00$ \\
\hline En Yüksek Hava Sıcaklığı $\left({ }^{\circ} \mathrm{C}\right) / \mathrm{h}$ & $22.6 / 14: 00$ \\
\hline En Düşük Bağıl Nem / Saat & $\% 29 / 15: 00$ \\
\hline En Yüksek Bağıl Nem / Saat & $\% 93 / 06: 00$ \\
\hline Gökyüzü Kondisyonu & Açık \\
\hline \multicolumn{2}{|l|}{ Tasarım Bilgileri } \\
\hline Senaryo 1 & $\% 40$ Yeșil alan \\
\hline Senaryo 2 & $\% 50$ Yeșil alan \\
\hline Senaryo 3 & $\% 60$ Yeșil alan \\
\hline Senaryo 4 & \% 70 Yeşil alan \\
\hline Senaryo 5 & $\% 80$ Yeşil alan \\
\hline
\end{tabular}


Daha önceden yapılan çalışmalarda da görülmektedir ki [1;25; 26; 27] sıcak iklime sahip bölgelerde dış mekan termal konforu saat 14:00 ile 16:00 arasında en olumsuz sonuçları vermektedir. Yapılan çalışmada bu verinin kış kentleri için geçerli olup olmadığı incelenmiş ve saat 15:00 için üretilen peyzaj tasarım senaryoları PMV parametresiyle değerlendirmeye alınmıştır.

\section{Bulgular}

Çalışma alanı için yapılan mevcut durum ve 5 öneri alan için Predicted Mean Vote (PMV) diş mekan termal konfor parametresine yönelik hazırlanan haritalara Şekil 2'de yer verilmiştir. Hazırlanan öneri peyzaj projelerinde yeşil alan oranı \% 40 ile \% 80 arasında değişmektedir. Mevcut durumda sıkıştırılmış toprak örtüsüne sahip arazinin park alanı olarak tasarlanması planlanarak her projede sert zemin ve yeşil alan oranları ve tasarımları değiştirilmiştir. Değerlendirmeler 3 farklı saat için gerçekleştirilmiştir. Çalışma kış aylarına yönelik olmasından kaynaklı değerlendirmeye alınan saatler insanların dış mekanları kullanım oranlarının fazla olduğu saatler olan 09:00, 12:00 ve 15:00 için dikkate alınmıştır. Buna ek olarak dış mekandaki malzemelerin enerjiyi depolayıp en fazla yansımayı ve dişa enerji yayma olayını yaptıkları 14:00 ile 16:00 aralığında saat 15:00 için değerlendirme yapılmıştır. [26; 28].

Değerlendirmeden elde edilen verilere göre saat 15:00 en sıcak ve termal konfor seviyesinin dikkat edilmesi gereken saat olarak teyit edilmiştir. Bununla birlikte hazırlanan haritalardaki renk aralığında yeşil renk dış mekan termal konforunun istenen seviyede olduğunu gösterirken, mavi renk soğuk stresini, kırmızı renk ise sıcak stresini tanımlamaktadir.

1 nolu senaryoda \% 40 oranında yeşil alan ve alan içerisinde su yüzeyi bulunmaktadır. Bu tasarımda saat 15:00 için sıcak stresinin oluştuğu tespit edilmiştir. \%50 oranında yeşil alan tasarlanan 2 nolu senaryoda ise saat 12:00 ve 15:00 için sıcak stresinin giderek arttığ gözlemlenmektedir. \%60 oranında yeşil alan bulunan 3 nolu senaryoda sıcak stresinin bulunduğu alanın oldukça az olduğu tespit edilmiştir. \% 70 oranda yeşil alan barındıran 4 nolu senaryoda saat 15:00 için alanda sıcak stresi 3 nolu senaryoya göre değişkenlik göstermemiştir. Son olarak en fazla yeşil alan bulunan 5 nolu tasarım projesinde sıcaklık stresi park alanı içerinde yok denecek kadar az miktarda tespit edilmiştir. Çalışma alanına ait mevcut durum ve senaryoların 3 farklı saat dilimine ait haritaları ve tasarımlarına Şekil 2'de yer verilmiştir. 


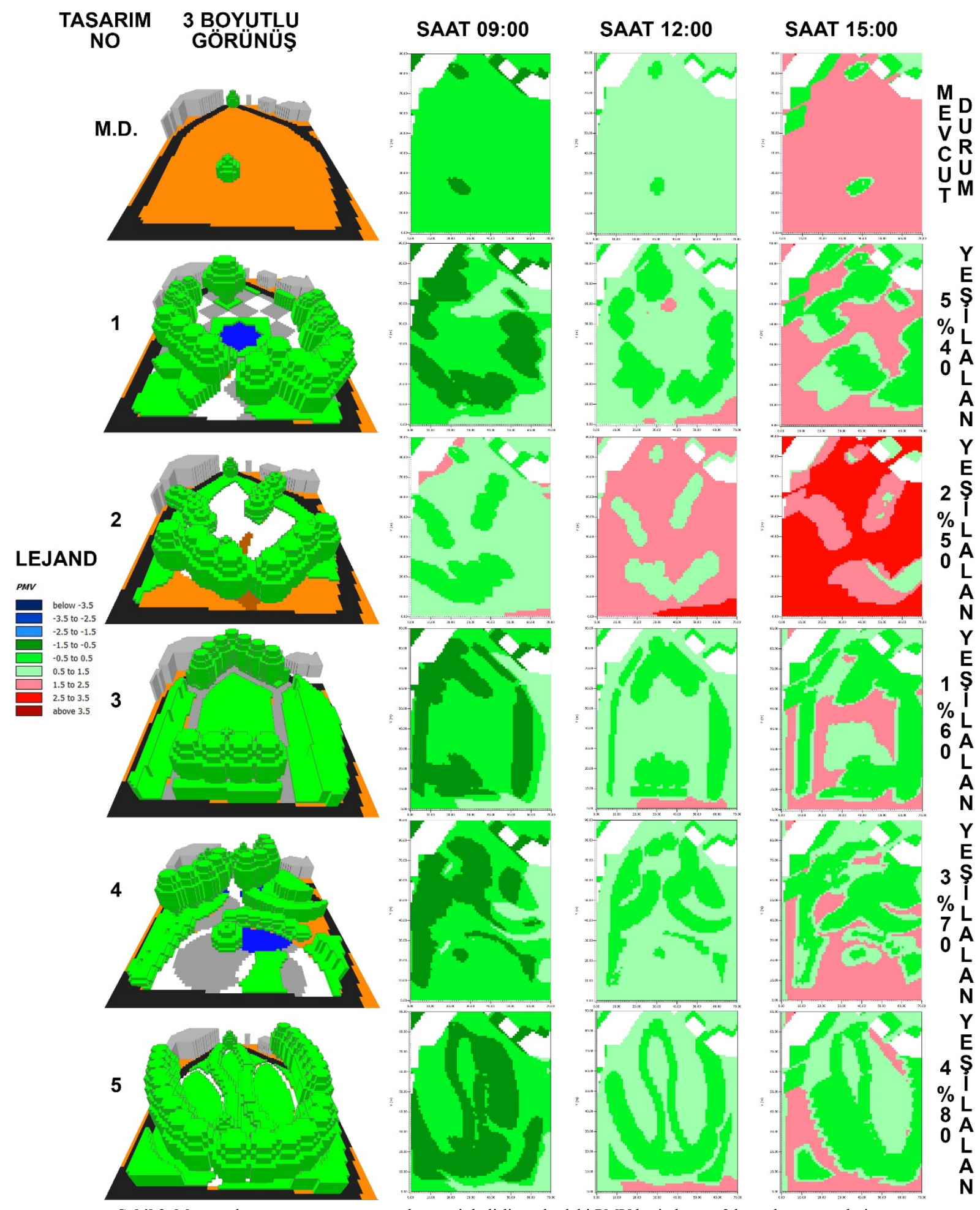

Çalışma alanlarına ait saat 09:00 (Şekil 3), saat 12:00 (Şekil 4) ve saat 15:00 (Şekil 5) için senaryoların ve mevcut durumun minimum ve maksimum PMV değerlerini içeren grafiklere yer verilmiştir. Elde edilen grafikler çalışma alanı olan parkın dışarısında yer alan araç yolu ve komşu ilişkinin kurulduğu çizime dahil bölgeleri de değerlendirmektedir. Bundan dolayı grafiklerdeki maksimum ve minimum değerlerin çalışmayı değerlendirmek adına doğru sonuçlar vermediği saptanmıştır. Bundan dolayı haritalamadaki renk aralığı değerlendirmeye alınmıştır. Değerlendirmede mavi ve tonları soğuk stresini, yeşil ve tonları konforlu aralığı, kırmızı ve tonları ise sıcak stresinin olduğu aralı̆̆ı temsil etmektedir. 
Nevşehir Bilim ve Teknoloji Dergisi (2019), 8(Enar Özel Sayı) 79-88

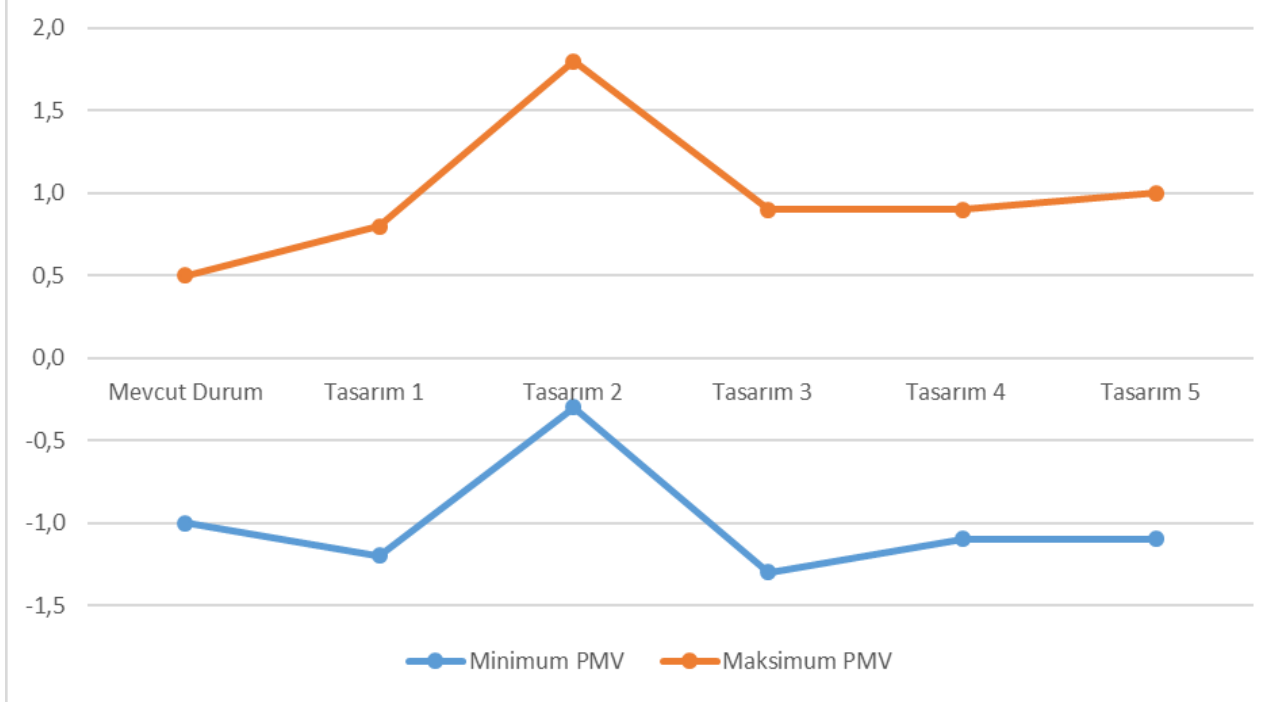

Şekil 3. Saat 09:00 için tasarımların maksimum ve minimum değerleri

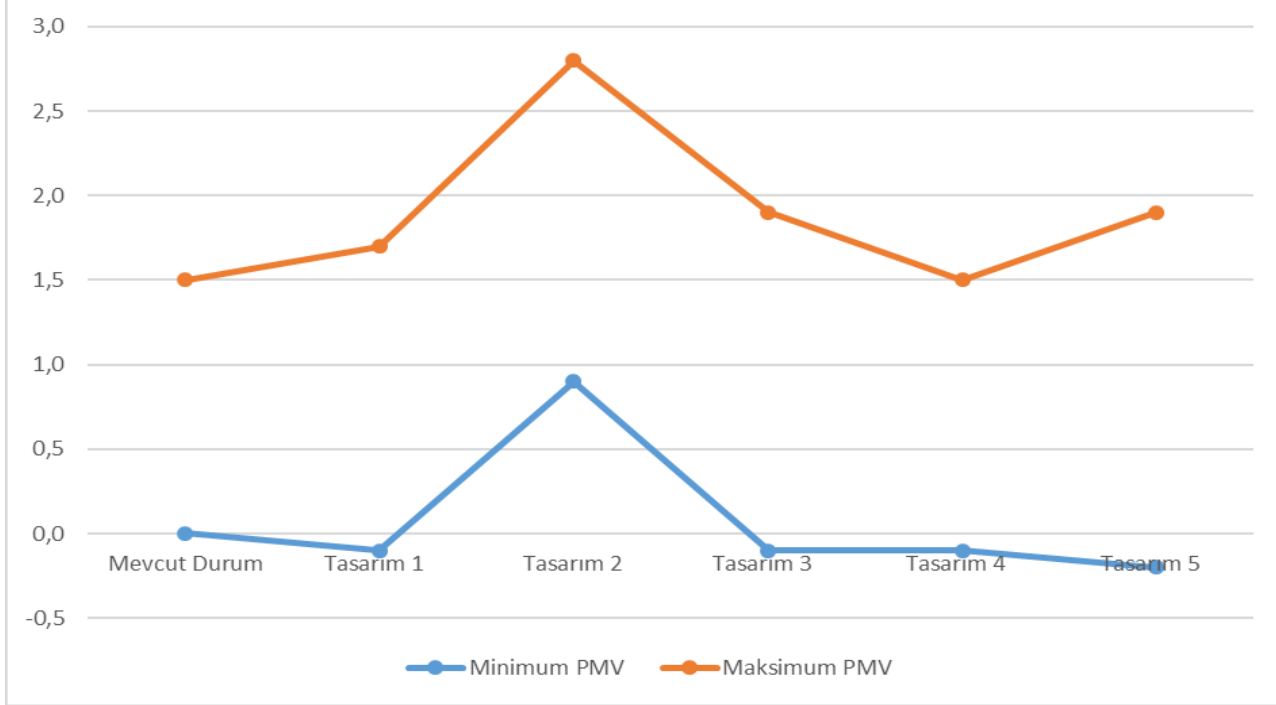

Şekil 4. Saat 12:00 için tasarımların maksimum ve minimum değerleri

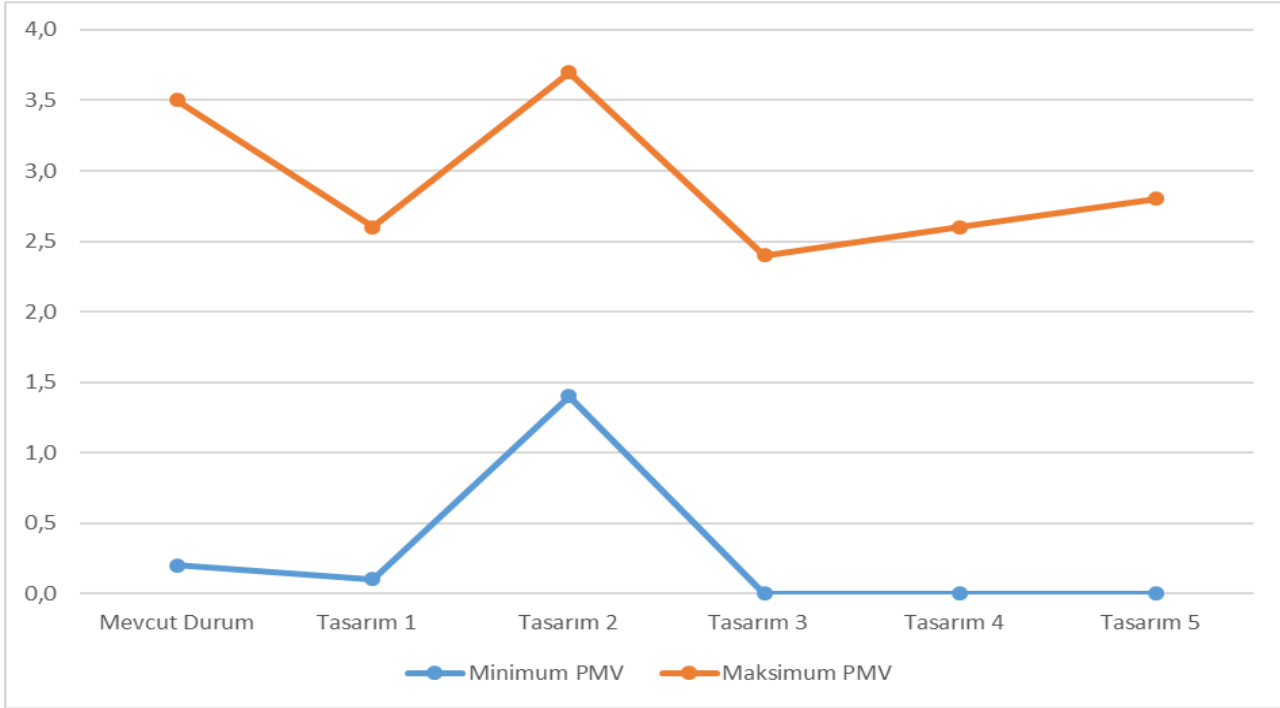

Şekil 5. Saat 15:00 için tasarımların maksimum ve minimum değerleri 


\section{Tartışma ve Sonuç}

Çalışma sonucundaki PMV haritaları da net olarak göstermektedir ki; yeşil alan oranı arttıkça alandaki dış mekan termal konforu da sağlanabilmektedir.

Dursun ve Yavaş yaptıkları çalışmada; Erzurum özelinde kış ayları için iklim odaklı tasarımlara yönelik yeşil alanların dışa kapalı formda sıcağı içeride tutacak şekilde uygulanmasını önermektedir [29]. Çalışma için yapılan tasarım senaryolarından sadece birisinde (\%50 yeşil alana sahip senaryo) bu öneri göz ardı edilmiş ve yaz ayları için de Dursun ve Yavaş’ın önerdiği tasarım kriterinin oldukça önem taşıdığı ortaya konulmuştur [29]. Çalışma alanında uygulanan tasarımlardan sadece \%50'si yeşil alan olarak tasarlanmış senaryoda sınır bölgelerinde çalı kullanılmamıştır. $\mathrm{Bu}$ da elde edilen PMV haritaları değerlendirildiğinde alan dışındaki asfalt yolun ve sert zemindeki sıcaklığın alan içerisine taşınmasına, kış aylarında da park içerisindeki sıcak havanın korunamamasına sebep olmaktadır. Bundan dolayı dış mekan termal konforu bakımından yeşil alan oranı önem kazanırken bir yandan da bitkilerin nerelerde ve nasıl kullanıldı̆̆ı da çok fazla önem taşımaktadır.

Yılmaz ve ark.'ın yaptığı çalışmada yaz ve kış aylarında ağaçların termal konforu arttırdığı sonucuna varılmıştır. Kış aylarındaki değerlendirmelerde ağaçlık alanların mevcut duruma göre ortamı $1.4{ }^{\circ} \mathrm{C}$ arttırdığı tespit edilirken, yaz aylarında ortamın sıcaklığını $1.2{ }^{\circ} \mathrm{C}$ düşürmüştür [27]. Yeşil alanların arttıkça dış mekan termal konforuna olumlu etki ettiği yapılan çalışmada da ortaya konmuş ve Yılmaz ve ark. ile benzer sonuçlar elde edilmiştir.

Çalışma alanının kuzey yarım kürede olduğu düşünüldüğünde; tasarımlarda yaya yollarının güney kıyıları ağaçlandırılmıştır. Bunun sonucu olarak ta güneş 1şınları yaya yollarına direkt olarak etki edememiştir. \%70’i yeşil alan olarak tasarlanan park için alanın güney kıyısında sert zemin kullanılmasından dolayı parkın güneyinde ağaç kullanılamamıştır. Bunun sonucu olarak alanın güney kıyısı saat 15:00 PMV haritasında sıcaklık stresine maruz kalmaktadır.

Mevcut duruma göre daha fazla sıcaklık stresinin çıktığı tek tasarım \%50 oranında yeşil alana sahip park tasarımıdır. Bunun sebebi olarak ise alanın mevcut durumunda toprak yüzeyle kapliyken yapılan tasarımda sert zemin ile kaplanması gösterilebilir.

\section{Kaynaklar}

[1] Sun, S., Xu, X., Lao, Z., Liu, W., Li, Z., García, E. H. and Zhu, J., 2017. Evaluating the impact of urban green space and landscape design parameters on thermal comfort in hot summer by numerical simulation, Building and Environment, V.123, p.277-288

[2] Mirzaei, P. A. and Haghighat, F., 2010. Approaches to study urban heat island-abilities and limitations, Building and environment, V.45(10), p.2192-2201

[3] Sarrat, C., Lemonsu, A., Masson, V. and Guedalia, D., 2006. Impact of urban heat island on regional atmospheric pollution, Atmospheric Environment, V.40(10), p.1743-1758

[4] UN., 2018. World Population Prospects 2017, United Nations DESA / Population Division

[5] IPCC, 2018. Intergovernmental Panel on Climate Change Global Warming of $1.5^{\circ} \mathrm{C}$

[6] Ketterer, C. and Matzarakis, A., 2014. Human-biometeorological assessment of heat stress reduction by replanning measures in Stuttgart, Germany, Landscape and Urban Planning, V.122, p.78-88

[7] Feyisa, G. L., Dons, K. and Meilby, H., 2014. Efficiency of parks in mitigating urban heat island effect: An example from Addis Ababa, Landscape and Urban Planning, V.123, p.87-95

[8] Yilmaz, S., Koç, A., Mutlu, E., \& Yildiz, N. D. (2016a). Integration of Thermal Comfort Information with Spatial Modelling in Erzurum City Center. Procedia engineering, 169, 80-87.

[9] Gómez, F., Cueva, A. P., Valcuende, M. and Matzarakis, A., 2013. Research on ecological design to enhance comfort in open spaces of a city (Valencia, Spain). Utility of the physiological equivalent temperature (PET), Ecological engineering, V.57, p.27-39

[10] Ruiz, M. A., Sosa, M. B., Correa, E. N. and Cantón, M. A., 2017. Design tool to improve daytime thermal comfort and nighttime cooling of urban canyons, Landscape and Urban Planning, V.167, p.249-256

[11] Chatzidimitriou, A. and Yannas, S., 2017. Street canyon design and improvement potential for urban open spaces; the influence of canyon aspect ratio and orientation on microclimate and outdoor comfort, Sustainable cities and society, V.33, p. 85-101 
[12] Yılmaz, H. \& Mutlu, E. (2018). Efficient Use of Squares in Winter Cities with Envimet Analysis and the Effects on Thermal Comfort. 10th International Conference on Urban Climate 14th Symposium on Urban Environment. 6-10 August 2018.

[13] Yilmaz, H., Yilmaz, S., Yavaş, M., Mutlu, E., \& Koç, A. (2016). Climate-sensitive pavement modelling for pedestrian ways. Procedia Engineering, 169, 408-415.

[14] Huang, K. T., Yang, S. R., Matzarakis, A. and Lin, T. P., 2018. Identifying outdoor thermal risk areas and evaluation of future thermal comfort concerning shading orientation in a traditional settlement, Science of The Total Environment, V.626, p.567-580

[15] Topay, M., 2013. Mapping of thermal comfort for outdoor recreation planning using GIS: the case of Isparta Province (Turkey), Turkish Journal of Agriculture \& Forestry, V.37(1), p.110-120

[16] Ketterer, C. and Matzarakis, A., 2016. Mapping the Physiologically Equivalent Temperature in urban areas using artificial neural network, Landscape and Urban Planning, V.150, p.1-9

[17] Yang, F. and Chen, L., 2016. Developing a thermal atlas for climate-responsive urban design based on empirical modeling and urban morphological analysis, Energy and Buildings, V.111, p.120-130

[18] Lai, P. C., Choi, C. C., Wong, P. P., Thach, T. Q., Wong, M. S., Cheng, W. and Wong, C. M., 2016. Spatial analytical methods for deriving a historical map of physiological equivalent temperature of Hong Kong, Building and Environment, V.99, p.22-28

[19] Lin, T. P., Chen, Y. C. and Matzarakis, A., 2017. Urban thermal stress climatic mapping: combination of longterm climate data and thermal stress risk evaluation, Sustainable Cities and Society, V.34, p.12-21

[20] Yu, C. and Hien, W. N., 2006. Thermal benefits of city parks, Energy and buildings, V.38(2), p.105-120

[21] Georgi, J. N., \& Dimitriou, D. (2010). The contribution of urban green spaces to the improvement of environment in cities: Case study of Chania, Greece. Building and environment, 45(6), 1401-1414.

[22] Oliveira, S., Andrade, H. and Vaz, T., 2011. The cooling effect of green spaces as a contribution to the mitigation of urban heat: A case study in Lisbon, Building and Environment, V.46(11), p.2186-2194

[23] Lin, W., Yu, T., Chang, X., Wu, W. and Zhang, Y., 2015. Calculating cooling extents of green parks using remote sensing: Method and test, Landscape and Urban Planning, V.134, p.66-75

[24] Anonymous, 2018. https://mgm.gov.tr/veridegerlendirme/il-ve-ilceler-istatistik.aspx?k=A\&m =ERZURUM, Accepted Date: 15.10 .2018

[25] Yahia, M. W. and Johansson, E., 2014. Landscape interventions in improving thermal comfort in the hot dry city of Damascus, Syria-The example of residential spaces with detached buildings, Landscape and Urban Planning, V.125, p.1-16

[26] Mutlu E., Yilmaz S., Yilmaz H. and Ertem Mutlu B., 2018. Analysis of Urban Settlement Unit By Envi-Met According To Different Aspects In Cold Regions. 6th Annual International Conference on Architecture and Civil Engineering (ACE 2018), Oral presentation, 14-15 May 2018, Singapore, p. 521-523, ISSN 2301-394X, doi: 10.5176/2301-394X_ACE18.97

[27] Yilmaz, S., Mutlu, E. and Yilmaz, H., 2018. Alternative scenarios for ecological urbanizations using ENVImet model, Environmental Science and Pollution Research, V.25(26), p.26307-26321

[28] Ünal Y., Topçu S., Menteş S., Yürük C., İlhan A., Temizöz H. P., Y1lmaz E., Doğan O. H., Buğday G., Özcan C., Kaytancı T., Karataş A., Dinç U., Kayaalp E. U., Erdemir P., Ünal Ş. Ç., Akgül H. B., Saymaz A. C., Saka F. B., Şimşek U. C., Ünal Z. F., İnan E., Kapan N., Diren D. H. and Somuncu G., 2017. Influence of Land Use Characteristics on Micro-Climate During a Heat Wave Episode on ITU Campus, 8th Atmospheric Sciences Symposium (ATMOS 2017), Poster presentation, 01-04 November 2017, Istanbul - Turkey, p. 771-777, ISBN 978-975561490-8

[29] Dursun, D. and Yavas, M., 2017. Soğuk İklime Duyarlı Kentsel Tasarım Yaklaşımları, Ĭgdır Üniversitesi Fen Bilimleri Enstitüsü Dergisi, V.7(2), p.269-278

[30] Bruse, M., 2017. ENVI-met 4: A Microscale Urban Climate Model. http://www.envi-met.info. [Accessed on February 2017]. 


\section{Extended Abstract}

In today's applied parks, hard floor rates are increasing and the use of plant material is decreasing. In addition, in most of the new parks, it is seen that plant materials with aesthetic value are used before functionality. As a result of these observations, it is curious to see how the increase of hard surfaces affected the climate in our cities.

The study area is located in the west of Erzurum Castle and is within the scope of urban transformation area. In the area with crushed land cover, which is used as a car parking area, designs with 5 different scenarios and hard floor rates were changed.

The designs were evaluated by ENVI-met program. As the hard floor ratio increases; climate-oriented outdoor thermal comfort was affected negatively in the study. These determinations were made according to Predicted Mean Vote (PMV) standards. In addition, it is observed that the use of plants and their places have gained importance. Factors that change positively the outdoor thermal comfort of the space in the park; the increase in green areas, the use of trees and the use of trees with shrubs.

\section{Introduction}

Especially in recent years, it is stated that the population rate in cities will increase and in 2025 it will be $60 \%$ of urban population in the world (United Nations, 2016). Accordingly, cities are growing more and more each day and population density in the unit area is increasing. Rapid urban settlements adversely affects the quality standards of living spaces and creates many environmental problems ranging from air pollution, distorted urbanization and the effect of urban heat island (UHI) to thermal uncomfortable spaces (Mirzaei et al., 2010). As a matter of fact, due to these problems, increasing disasters caused damage to more than 220 million people as well as property damage (UN-Habitat, 2018). The micro-climatic characteristics of the environment should be taken into consideration in the landscape design of the parks. Failure to consider the microclimate in the wrong preferences or planning creates thermal uncomfortable spaces.

\section{Method}

The city of Erzurum, which is one of the highest settlements in our country, is at an altitude of $1890 \mathrm{~m}$ and the average temperature for long years is $5.6^{\circ} \mathrm{C}$. The city is $25.066 \mathrm{~km}^{2}$ in the northeast of the Eastern Anatolia Region [24]. . A three-dimensional micro-climatic 3D modelling tool ENVI-met V4.2 Summer was used to evaluate meteorological data. At the time of modeling, the most used time of the area was taken at 14:00. Although different versions of this software is available, the underlying logic is always the same (Bruse2017). While measuring the temperature values with the precision thermometer (WS300), the humidity values were taken with the YCOM-KMN 305 model temperature and humidity meter. TROTEC BA16 model anemometer is used for wind speed measurement.

\section{Results and Discussion}

It is difficult and cost-effective to design existing and already used parks in cities according to microclimate. However, when planning new settlements, climate-based parking designs should be included. Proper planning is essential for sustainable urbanization. Livable city with thermal comfort provides physical and physiological advantaged for human. In this study the aim is to; produce alternative scenarios using different plants, water and ground covering materials and to present comfortable places for people in terms of climate. As a result, as the ratio of green space usage for the designed parking area decreases; It has been determined that the thermal comfort of the outdoor thermal comfort shifts from the "Comfortable" range to the "Slight Heat Stress" or "Modereta Heat Stress" range. It was emphasized in this study that it is mandatory to work as a multidisciplinary team for establishing a healthy, sustainable and livable smart urbanization with thermal comfort. 
Nevşehir Bilim ve Teknoloji Dergisi (2019), 8(Enar Özel Sayı) 79-88 